\title{
BMJ
}

\section{Association of active and passive smoking with risk of breast cancer among postmenopausal women: a prospective cohort study}

\author{
Juhua Luo, assistant professor, ${ }^{1}$ Karen L Margolis, senior clinical investigator, ${ }^{2}$ Jean Wactawski-Wende, \\ professor and associate chair, ${ }^{3}$ Kimberly Horn, associate professor, ${ }^{1}$ associate center director, ${ }^{4}$ Catherine \\ Messina, research associate professor , ${ }^{5}$ Marcia L Stefanick, professor, ${ }^{6}$ Hilary A Tindle, assistant professor of \\ medicine, ${ }^{7}$ Elisa Tong, assistant professor, ${ }^{8}$ Thomas E Rohan, professor ${ }^{9}$
}

1Department of Community Medicine, Mary Babb Randolph Cancer Center, West Virginia University, Morgantown, WV, USA

${ }^{2}$ HealthPartners Research Foundation, Box 1524, Mailstop 21111R, Minneapolis, MN 554401524, USA

${ }^{3}$ Department of Social and Preventive Medicine, University at Buffalo, Buffalo, NY, USA

${ }^{4}$ WV Prevention Research Center, West Virginia University

${ }^{5}$ Department of Preventive Medicine, Stony Brook University, NY, USA

${ }^{6}$ Stanford University School of Medicine, CA, USA

${ }^{7}$ Center for Research on Health Care, Division of General Internal Medicine, University of Pittsburgh, Pittsburgh, PA, USA

${ }^{8}$ Division of General Internal Medicine, University of California, Davis Medical Center, Sacramento, CA, USA

${ }^{9}$ Department of Epidemiology \& Population Health, Albert Einstein College of Medicine, Bronx, NY, USA

Corresponding to: $\mathrm{K} \mathrm{L}$ Margolis Karen.L.Margolis@HealthPartners. com

Cite this as: BMJ 2011;342:d1016 doi:10.1136/bmj.d1016

\section{ABSTRACT}

Objective To examine the association between smoking and risk of invasive breast cancer using quantitative measures of lifetime passive and active smoking exposure among postmenopausal women.

Design Prospective cohort study.

Setting 40 clinical centres in the United States.

Participants 79990 women aged 50-79 enrolled in the Women's Health Initiative Observational Study during 1993-8.

Main outcome measures Self reported active and passive smoking, pathologically confirmed invasive breast cancer.

Results In total, 3520 incident cases of invasive breast cancer were identified during an average of 10.3 years of follow-up. Compared with women who had never smoked, breast cancer risk was elevated by $9 \%$ among former smokers (hazard ratio 1.09 ( $95 \% \mathrm{Cl} 1.02$ to 1.17$)$ ) and by $16 \%$ among current smokers (hazard ratio 1.16 (1.00 to 1.34)). Significantly higher breast cancer risk was observed in active smokers with high intensity and duration of smoking, as well as with initiation of smoking in the teenage years. The highest breast cancer risk was found among women who had smoked for $\geq 50$ years or more (hazard ratio 1.35 (1.03 to1.77) compared with all lifetime non-smokers, hazard ratio 1.45 (1.06 to 1.98) compared with lifetime non-smokers with no exposure to passive smoking). An increased risk of breast cancer persisted for up to 20 years after smoking cessation. Among women who had never smoked, after adjustment for potential confounders, those with the most extensive exposure to passive smoking ( $\geq 10$ years' exposure in childhood, $\geq 20$ years' exposure as an adult at home, and $\geq 10$ years' exposure as an adult at work) had a $32 \%$ excess risk of breast cancer compared with those who had never been exposed to passive smoking (hazard ratio 1.32 (1.04 to 1.67)). However, there was no significant association in the other groups with lower exposure and no clear dose response to cumulative passive smoking exposure.
Conclusions Active smoking was associated with an increase in breast cancer risk among postmenopausal women. There was also a suggestion of an association between passive smoking and increased risk of breast cancer.

\section{INTRODUCTION}

Experimental studies have shown that compounds found in tobacco smoke, such as polycyclic hydrocarbons, aromatic amines, and $\mathrm{N}$-nitrosamines, may induce mammary tumours. ${ }^{1}$ The detection of smoking-specific DNA adducts and mutations in the p53 gene in the breast tissue of smokers supports the biological plausibility of a positive association between cigarette smoking and breast cancer. ${ }^{2-6}$ Despite this mechanistic evidence, systematic reviews of epidemiological studies published as of 2002 concluded that there was no overall association between active smoking and breast cancer risk, and attributed conflicting results of individual studies in part to the confounding effects of alcohol. ${ }^{17-10}$ However, recent reappraisals of evidence $^{1112}$ from recent cohort studies ${ }^{13-19}$ have suggested an increased risk of breast cancer that is independent of the effects of alcohol among women who smoked cigarettes for a long period of time or who started smoking at a young age.

Similarly, studies of passive smoking suggest an increased risk of breast cancer, particularly case-control studies that have conducted a more thorough assessment of exposure. ${ }^{20-24}$ These reports found stronger evidence of an association of passive smoking and breast cancer in younger, primarily premenopausal women, whereas the evidence in older or postmenopausal women was inconclusive. Although cohort studies are generally considered less subject to bias than case-control studies, assessment of passive smoking has generally been less comprehensive in large cohort studies than in case-control studies. ${ }^{1625-29}$ Despite limited evaluations of exposure, which may lead to exposure misclassification and bias the relative risk towards the null, several of these studies found 
associations of passive smoking with breast cancer in subgroups of women who reported being more heavily exposed. $^{27-29}$ Only one published cohort study includes full information on three major aspects of lifetime exposure to passive smoking (childhood, adult residential, and adult occupational), and this study found increased breast cancer risk in a heavily exposed subgroup. $^{30}$ Thus, prospective studies with more detailed assessment of passive smoking are needed to elucidate the association of passive smoking and breast cancer risk, especially in postmenopausal women.

In the Women's Health Initiative Observational Study, detailed information regarding active and passive smoking exposure was collected, including questions on passive exposure to cigarette smoke in childhood and adult exposure both in the home and at work. In the present study, we used data from the Women's Health Initiative that included a large number of breast cancer cases and detailed exposure information to address the relation between active and passive smoking and the risk of breast cancer in postmenopausal women. Further, given that breast cancer is a heterogeneous disease with subtypes that may vary in their aetiologies, we explored whether the effects of active or passive smoking differed by disease subgroups defined by hormone receptor status or histology.

\section{METHODS}

\section{Women's Health Initiative}

The Women's Health Initiative Observational Study was designed to address major causes of morbidity and mortality in postmenopausal women. ${ }^{31}$ A total of 93676 women aged 50-79 were recruited at 40 clinical centres throughout the United States from 1993 to 1998. ${ }^{3233}$ Women were excluded if they did not plan to reside in the area for at least three years, if they had conditions predictive of survival less than three years, or had complicating conditions such as alcoholism, drug dependency, or dementia. The study was overseen by ethics committees at all 40 clinical centres and at the coordinating centre, as well as by a data and safety monitoring board. All participants in the study gave informed consent and were followed prospectively. Of the original cohort of 93676 , we excluded 12075 with a history of cancer (except nonmelanoma skin cancer) at baseline, 443 who had no follow-up time, and 1168 with missing values of smoking status. This yielded a sample of 79990 women for further analysis.

\section{Measurement of exposures and confounders}

All information on exposures and confounders used in this analysis was collected at baseline. Information on active smoking included smoking status (never, former, or current), and women who were current or former smokers were also asked the age at which they started smoking, the number of cigarettes smoked per day, and the duration of smoking in years. Among former smokers, age at quitting smoking was also collected. Pack years of smoking were calculated by multiplying the total years of smoking by the number of cigarettes smoked a day divided by 20 .

Questions on exposure to passive smoking related to each of the following: childhood $(<18$ years old), adult home, adult work, current home, and current work (yes or no). Women who reported any of these exposures were also asked the number of years of exposure in childhood, as an adult at home, and as an adult at work (predefined categories $<1,1-4,5-9,10-18$ for childhood exposure; <1, 1-4, 5-9, 10-19, 20-29, 30$39, \geq 40$ for adult exposure at home or work).

The potential confounders used in multivariable analyses included age at enrolment $(<55,55-59,60$ $64,65-69,70-74, \geq 75$ years), ethnicity (American Indian or Alaska native, Asian or Pacific Islander, black or African-American, Hispanic or Latino, nonHispanic white, and other), education (high school or less, some college or technical training, college or some post-college, and master's degree or higher), body mass index $(<18.5,18.5-24.9,25.0-29.9$, 30.0-34.9, 35.0-39.9, $\geq 40$ ), physical activity (metabolic equivalent tasks per week $<5,5-<10,10-<20,20<<30, \geq 30$ ), alcohol intake (non-drinker, former drinker, $<1$ drink/ month, 1 drink/month $<1$ drink/week, 1-<7 drinks/ week, $\geq 7$ drinks/week), parity (never pregnant, never had term pregnancy, 1, 2, 3, 4, $\geq 5$ ), family history of breast cancer (yes/no), history of hormone therapy use (none, oestrogen alone, oestrogen and progestin, mixed), age at menarche $(\leq 12,12-13,14-15$, $\geq 16$ years), and age of first live birth (never had term pregnancy, $<20,20-29, \geq 30$ years).

\section{Follow-up and ascertainment of cases}

Initial reports of cancer were ascertained by annual self administered questionnaires, and all reports of breast cancer were confirmed by review of medical records, including pathology reports (if a biopsy or resection was done). The breast cancer cases were then coded by an experienced coder in accordance with the coding guidelines from Surveillance Epidemiology and End Results. ${ }^{34}$ Primary tumour site and histology were coded in accordance with the ICD-O-2 (international classification of diseases for oncology, second edition). The completion rate of annual questionnaires was 93\%-96\%.

In this study, we included only invasive breast cancer cases; cases of carcinoma in situ were not included. By 14 August 2009, with an average 10.3 years of follow-up, 3520 incident cases of invasive breast cancer had been identified. Among 41022 women who had never smoked, 1692 cases were identified, and these cases were used for the passive smoking analysis.

\section{Statistical analysis}

Analysis of the association of passive smoking with breast cancer risk was limited to the 41022 women who had never smoked. Before analysing the data, we developed a method to combine data on all passive smoking exposures, including exposure during childhood, adult home exposure, and work exposure. We constructed a new variable using the mutually 
Table 1|Baseline characteristics of 79990 postmenopausal women by diagnosis of invasive breast cancer (values are numbers (percentages) of women unless stated otherwise)

\begin{tabular}{|c|c|c|c|}
\hline Variable & Cases & Non-cases & $\begin{array}{l}\text { P value of } \\
\text { difference* }\end{array}$ \\
\hline Total No of women & 3520 & 76470 & \\
\hline Mean (SD) age at baseline (years) & $63.7(7.1)$ & $63.4(7.3)$ & 0.006 \\
\hline Mean (SD) body mass index $\left(\mathrm{kg} / \mathrm{m}^{2}\right)$ & $27.4(5.7)$ & $27.2(5.8)$ & 0.07 \\
\hline Mean (SD) physical activity (METs/week) & $13.7(13.6)$ & $13.8(14.4)$ & 0.8 \\
\hline Non-Hispanic white ethnicity & $3126(88.8)$ & $63356(82.9)$ & $<0.0001$ \\
\hline Higher educational status $\dagger$ & $1674(47.6)$ & 31827 (41.6) & $<0.0001$ \\
\hline Age at menarche $\varangle 12$ years & $439(12.5)$ & $8792(11.5)$ & 0.2 \\
\hline \multicolumn{4}{|l|}{ Hormone therapy use: } \\
\hline Oestrogen alone & $986(28.0)$ & $23714(31.0)$ & \multirow{3}{*}{$<0.0001$} \\
\hline Oestrogen plus progestin & $1082(30.7)$ & $17842(23.3)$ & \\
\hline Mixed use & $262(7.4)$ & $4699(6.1)$ & \\
\hline Nulliparous & $496(14.1)$ & $9484(12.4)$ & $<0.0001$ \\
\hline Age at first live birth $\geq 30$ years & $337(9.6)$ & $5695(7.5)$ & $<0.0001$ \\
\hline Alcohol intake $\geq 7$ drinks/week & $552(15.7)$ & $9418(12.4)$ & $<0.0001$ \\
\hline Family history of breast cancer & $812(23.1)$ & $13379(17.5)$ & $<0.0001$ \\
\hline \multicolumn{4}{|l|}{ Smoking status: } \\
\hline Never smoked: & $1692(48.1)$ & $39330(51.4)$ & \multirow{9}{*}{$<0.0001$} \\
\hline \multicolumn{4}{|l|}{ Exposure to passive smoking: } \\
\hline None & $145(8.6)$ & $3609(9.2)$ & \\
\hline Childhood only & $110(6.5)$ & $2241(5.7)$ & \\
\hline Adult at home only & $88(5.2)$ & $2436(6.2)$ & \\
\hline Adult at work only & $199(11.8)$ & $4800(12.2)$ & \\
\hline More than one type & $1118(66.1)$ & $25132(63.9)$ & \\
\hline Unknown & $32(1.9)$ & $1112(2.8)$ & \\
\hline Former smokers & $1619(46.0)$ & $32371(42.3)$ & \\
\hline Current smokers & $209(5.9)$ & $4769(6.2)$ & \\
\hline
\end{tabular}

$\mathrm{SD}=$ standard deviation. $\mathrm{MET}=$ metabolic equivalent tasks.

${ }^{*} \mathrm{X}^{2}$ test between cases and non-cases. Significant for age, race, education, hormone therapy use, parity, age of first live birth, alcohol intake, and family history of breast cancer (all P values 20.05 ).

†College graduate or above. based on the work of Hammond et al. ${ }^{3536}$ Finally, we examined additional categories of dual and triple exposure based on our original dichotomous variables, including the "extensive exposure" group defined a priori.

We estimated hazard ratios for active smoking compared with two reference groups. In the primary analysis, the reference group was lifetime non-smokers; in a secondary analysis we used the much smaller reference group of lifetime non-smokers with no history of passive smoking.

Cox proportional hazards regression models were used to estimate hazard ratios and 95\% confidence intervals, adjusting for the potential confounders described above in measurement of exposure and confounders. Participants without complete data for all covariates in a given multivariable model were excluded from that analysis. Follow-up time for each woman was accrued from enrolment to the date of diagnosis of invasive breast cancer, death, loss to follow-up (including non-participation in an extension of the study starting in 2005), or the administrative censoring date (14 August 2009), whichever occurred first. Tests for trend were performed by using the ordered category, including the reference, as a continuous variable in the proportional hazard model. The proportionality assumption was satisfied for all exposure variables of interest and potential confounding variables based on graphs of scaled Schoenfeld residuals. ${ }^{37}$ All statistical analyses were conducted using SAS (Version 9.0, SAS Institute, Cary, NC).

\section{RESULTS}

Table 1 shows the baseline characteristics of the study subjects by disease status. Women who developed invasive breast cancer were slightly older than women who did not, but their body mass index and physical activity were similar. Compared with women who remained free of breast cancer, those who developed the disease were significantly more likely to be non-Hispanic white, more highly educated, nulliparous, older at first live birth, and to have a history of taking oestrogen plus progesterone hormone therapy, heavier alcohol intake, and a family history of breast cancer (all $\mathrm{P}$ values $<0.05$ ). Women who developed breast cancer were also less likely to have never smoked that those who did not develop cancer (48.1\% v 51.4\%). Among lifetime non-smokers, 88.1\% were exposed to passive smoking, and most women had multiple types of passive smoking exposure. Childhood exposure only was slightly higher among the non-smokers who developed breast cancer than those who did not, as was multiple types of passive smoking exposure (table 1).

Among women who had never smoked, we did not observe a significant association between breast cancer risk and passive smoking except for the highest level of exposure (childhood exposure $\geq 10$ years, adult home exposure $\geq 20$ years, and adult work exposure $\geq 10$ years) (table 2). We also did not observe a significant dose-response trend for any method of estimating 
Table 2 | Cases of incident invasive breast cancer and related hazard ratios associated with exposure to passive smoking among 41022 postmenopausal women who had never smoked

\begin{tabular}{|c|c|c|c|}
\hline \multirow[b]{2}{*}{ Exposure to passive smoking } & \multirow[b]{2}{*}{ No of cases } & \multicolumn{2}{|c|}{ Hazard ratio $(95 \% \mathrm{Cl})$} \\
\hline & & Age adjusted & Multivariable adjusted* \\
\hline None & 145 & 1.00 (reference) & 1.00 (reference) \\
\hline Any: & 1515 & $1.08(0.91$ to 1.28$)$ & 1.09 (0.92 to 1.29$)$ \\
\hline Childhood only & 110 & $1.22(0.95$ to 1.56$)$ & $1.19(0.93$ to 1.53$)$ \\
\hline Adult at home only & 88 & $0.89(0.69$ to 1.16$)$ & 0.91 (0.70 to 1.19$)$ \\
\hline Adult at work only & 199 & $1.02(0.83$ to 1.27$)$ & $1.01(0.82$ to 1.26$)$ \\
\hline Childhood + adult at home & 170 & $1.02(0.81$ to 1.27$)$ & 1.04 (0.83 to 1.30$)$ \\
\hline Childhood + adult at work & 191 & $1.18(0.95$ to 1.47$)$ & $1.17(0.94$ to 1.45$)$ \\
\hline Adult at home + at work & 236 & $1.12(0.91$ to 1.38$)$ & $1.15(0.93$ to 1.41$)$ \\
\hline Childhood + adult at home + at work & 521 & $1.09(0.90$ to 1.31$)$ & $1.11(0.92$ to 1.34$)$ \\
\hline \multicolumn{4}{|l|}{ Cumulative exposure categories: } \\
\hline No childhood + any adult & 524 & 1.04 (0.86 to 1.24$)$ & $1.05(0.87$ to 1.26$)$ \\
\hline Childhood $<10$ years + any adult & 154 & $1.10(0.88$ to 1.39$)$ & $1.13(0.90$ to 1.42$)$ \\
\hline Childhood $\geq 10$ years + adult at home $<20$ years + adult at work $<10$ years & 421 & 1.14 (0.95 to 1.38$)$ & $1.13(0.94$ to 1.37$)$ \\
\hline Childhood $\geq 10$ years + adult at home $<20$ years + adult at work $\geq 10$ years & 151 & $0.99(0.79$ to 1.24$)$ & $0.98(0.77$ to 1.23$)$ \\
\hline Childhood $\geq 10$ years + adult at home $\geq 20$ years + adult at work $<10$ years & 124 & $0.99(0.78$ to 1.25$)$ & $1.05(0.82$ to 1.33$)$ \\
\hline Childhood $\geq 10$ years + adult at home $\geq 20$ years + adult at work $\geq 10$ years $\dagger$ & 146 & 1.27 (1.01 to 1.60$)$ & $1.32(1.04$ to 1.67$)$ \\
\hline P value for trend§ & & 0.16 & 0.10 \\
\hline \multicolumn{4}{|c|}{$\begin{array}{l}\text { *Variables used in multivariable models included age at enrolment, ethnicity, education, body mass index, physical activity, alcohol intake, parity, } \\
\text { family history of breast cancer, hormone therapy use, age at menarche, and age of first live birth. } \\
\dagger \text { The "extensive exposure" variable defined a priori. } \\
\text { §Including the reference group (no exposure) and the } 6 \text { rows of cumulative exposure categories. }\end{array}$} \\
\hline
\end{tabular}

cumulative exposure, with all the estimates being qualitatively similar to the categorical results shown in table 2 . In the women who had never smoked with the most extensive exposure to passive smoking, we observed a $32 \%(95 \%$ confidence interval $4 \%$ to $67 \%)$ excess risk of breast cancer (table 2).

We assessed the risk of breast cancer associated with different measures of active smoking by including or excluding passive smokers in the reference category who had never smoked (table 3 ). In the primary analysis, with all lifetime non-smokers as the reference group, breast cancer risk was elevated by $9 \%$ (2\% to $17 \%)$ among former smokers and by $16 \%(0 \%$ to $34 \%, \mathrm{P}=0.05$ ) among current smokers. Compared with never smoking, the risk of breast cancer was positively associated with smoking intensity, smoking duration, and pack years of cigarette smoking, and inversely associated with age at smoking initiation. Compared with never smokers who had at least one full term pregnancy, women who began smoking before their first full term pregnancy had a $21 \%(11 \%$ to $33 \%$ ) elevated risk of breast cancer. All trend tests were statistically significant. The highest breast cancer risk was found among women who had smoked for $\geq 50$ years (hazard ratio 1.35 (1.03 to 1.77$)$ ). Among former smokers, the years since quitting smoking was significantly inversely associated with breast cancer risk. An increased risk of breast cancer persisted for up to 20 years after smoking cessation.

Since extensive exposure to passive smoking was associated with increased breast cancer risk, which could result in underestimating the risks of active smoking, we conducted a secondary analysis using lifetime non-smokers with no history of any exposure to passive smoke as the reference group. In general, the point estimates of active smoking risks in this secondary analysis were higher than those based on inclusion of passive smokers in the reference group but were less precise because of the much smaller size of the reference group. The hazard ratio for breast cancer among current smokers was significantly elevated $(\mathrm{P}<0.05)$ regardless of the reference group used, as was the risk among women who started smoking before their first term pregnancy, smoked for $\geq 50$ years, or had $\geq 50$ pack years of smoking (table 3).

Finally, we assessed the association between smoking exposure and the risk of breast cancer for different types of breast cancer (table 4). There was no significant association of extensive passive smoking with any breast cancer type, but statistical power was limited by the small sample sizes. There was a non-significant trend towards a stronger association of current smoking with lobular cancer than with ductal cancer $(\mathrm{P}$ for interaction=0.13). Although there was a significant association of former and current smoking with tumours that were hormone receptor positive (for both oestrogen and progesterone, the dominant subtype), statistical power was probably too limited to assess whether this was true with other hormone receptor subtypes (Pfor interaction $>0.2$ ) (table 4 ). When we examined the associations of the different variables of active smoking (including age of smoking initiation, intensity, duration, and pack years of smoking) on the risk of breast cancer for these subgroups, we found similar patterns to that of breast cancer overall for dominant subtypes (ductal cancer and hormone receptor positive) and no clear pattern for other subtypes (data not shown). 
Table 3 |Cases of incident invasive breast cancer and related hazard ratios associated with smoking status among 79990 postmenopausal women

\begin{tabular}{lccc} 
& No of & \multicolumn{2}{c}{ Hazard ratio $(95 \% \mathrm{Cl})$} \\
\cline { 3 - 4 } Smoking status & cases & Multivariable adjusted & Multivariable adjusted \\
Never smoked: & 1692 & 1.00 (reference) & - \\
\hline With no exposure to passive smoking & 145 & - & 1.00 (reference) \\
\hline With exposure to passive smoking & 1515 & - & $1.08(0.91$ to 1.28$)$ \\
\hline Former smokers & 1619 & $1.09(1.02$ to 1.17$)$ & $1.16(0.98$ to 1.38$)$ \\
\hline Current smokers & 209 & $1.16(1.00$ to 1.34$)$ & $1.24(1.00$ to 1.54$)$ \\
\hline Age at starting smoking (years): & & & \\
\hline 15 & 112 & $1.12(0.92$ to 1.36$)$ & $1.19(0.93$ to 1.53$)$ \\
\hline $15-19$ & 940 & $1.13(1.04$ to 1.23$)$ & $1.21(1.01$ to 1.44$)$ \\
\hline $20-24$ & 581 & $1.09(0.99$ to 1.20$)$ & $1.16(0.97$ to 1.40$)$ \\
\hline $25-29$ & 110 & $1.02(0.84$ to 1.24$)$ & $1.09(0.85$ to 1.40$)$ \\
\hline$\geq 30$ & 80 & $0.94(0.75$ to 1.18$)$ & $1.00(0.76$ to 1.32$)$ \\
\hline P value for trend & & 0.002 & 0.04 \\
\hline
\end{tabular}

Smoking started before first term

pregnancył:

\begin{tabular}{llll}
\hline Yes & 833 & $1.21(1.11$ to 1.33$)$ & $1.28(1.06$ to 1.55$)$ \\
\hline No & 116 & $1.12(0.92$ to 1.36$)$ & $1.17(0.90$ to 1.52$)$ \\
\hline Uncertain & 618 & $1.07(0.97$ to 1.18$)$ & $1.13(0.93$ to 1.37$)$ \\
\hline Average No of cigarettes smoked/day: & & & \\
\hline$\langle 5$ & 383 & $1.05(0.94$ to 1.17$)$ & $1.12(0.92$ to 1.35$)$ \\
\hline $5-14$ & 560 & $1.11(1.01$ to 1.23$)$ & $1.19(0.99$ to 1.43$)$ \\
\hline $15-24$ & 503 & $1.14(1.03$ to 1.27$)$ & $1.22(1.01$ to 1.47$)$ \\
\hline$\geq 25$ & 301 & $1.08(0.95$ to 1.22$)$ & $1.15(0.94$ to 1.41$)$ \\
\hline
\end{tabular}

$\mathrm{P}$ value for trend

0.01

0.16

Total No of smoking years:

\begin{tabular}{lccc}
\hline$\ll 5$ & 220 & $0.97(0.84$ to 1.11$)$ & $1.03(0.86$ to 1.28$)$ \\
\hline $5-9$ & 182 & $1.05(0.90$ to 1.22$)$ & $1.12(0.90$ to 1.40$)$ \\
\hline $10-19$ & 401 & $1.09(0.98$ to 1.22$)$ & $1.17(0.96$ to 1.42$)$ \\
\hline $20-29$ & 387 & $1.09(0.97$ to 1.22$)$ & $1.16(0.96$ to 1.41$)$ \\
\hline $30-39$ & 341 & $1.21(1.07$ to 1.36$)$ & $1.29(1.06$ to 1.58$)$ \\
\hline $40-49$ & 178 & $1.14(0.98$ to 1.34$)$ & $1.22(0.98$ to 1.53$)$ \\
\hline$\geq 50$ & 56 & $1.35(1.03$ to 1.77$)$ & $1.45(1.06$ to 1.98$)$ \\
\hline P value for trend & & 0.0002 & 0.002
\end{tabular}

No of smoking pack years:

\begin{tabular}{|cccc}
\hline$\ll 10$ & 702 & $1.04(0.95$ to 1.14$)$ & $1.11(0.93$ to 1.33$)$ \\
\hline $10-<20$ & 359 & $1.21(1.08$ to 1.36$)$ & $1.29(1.06$ to 1.58$)$ \\
\hline $20-30$ & 225 & $1.13(0.98$ to 1.30$)$ & $1.21(0.98$ to 1.50$)$ \\
\hline $30-\ll 40$ & 168 & $1.01(0.86$ to 1.19$)$ & $1.08(0.86$ to 1.36$)$ \\
\hline $40-\ll 50$ & 69 & $1.16(0.91$ to 1.47$)$ & $1.24(0.92$ to 1.65$)$ \\
\hline$\geq 50$ & 218 & $1.18(1.02$ to 1.37$)$ & $1.26(1.02$ to 1.57$)$ \\
\hline P value for trend & & 0.005 & 0.08
\end{tabular}

Years since quitting smoking

(former smokers):

\begin{tabular}{llcc}
\hline$\ll 10$ & 295 & $1.15(1.01$ to 1.31$)$ & $1.19(0.96$ to 1.47$)$ \\
\hline $10-\ll 20$ & 416 & $1.14(1.02$ to 1.27$)$ & $1.17(0.96$ to 1.43$)$ \\
\hline $20-\ll 30$ & 391 & $1.08(0.96$ to 1.21$)$ & $1.11(0.91$ to 1.36$)$ \\
\hline$\geq 30$ & 414 & $1.06(0.95$ to 1.18$)$ & $1.08(0.89$ to 1.32$)$ \\
\hline P value for trend & & 0.005 & 0.08
\end{tabular}

${ }^{*}$ Reference category was lifetime non-smokers.

†Reference category was lifetime non-smokers with no history of exposure to passive smoking.

¥Among 69533 women who had at least one full term pregnancy, 1429 cases were among never smokers and

125 cases in no exposure group.

\section{DISCUSSION}

In this large prospective study in postmenopausal women, we observed an elevated risk of breast cancer in former smokers $(9 \%)$ and current smokers $(16 \%)$, particularly with smoking of high intensity, of long duration, and which started at an early age. Among former smokers, the time since quitting smoking was significantly inversely associated with breast cancer risk, and it took up to 20 years for a former smoker's risk to return to baseline. Finally, we observed a 32\% excess risk of breast cancer associated with the most extensive exposure to passive smoking among women who had never been active smokers.

\section{Comparison with other studies}

Until recently, most scientists agreed that there was not enough consistent evidence to determine whether active smoking plays a causal role in breast cancer. ${ }^{17-10}$ However, a Canadian panel of experts reviewed the extensive new research in this area and concluded that the relations between active smoking and breast cancer, both premenopausal and postmenopausal, are consistent with causality, based on the weight of evidence from epidemiological and toxicological studies and on an understanding of biological mechanisms. ${ }^{12}$ Our findings on active smoking are consistent with the most recent studies reporting a risk elevation of around 20\%-50\% in association with high intensity smoking of long duration and with early age at smoking initiation or smoking initiation before their first pregnancy among postmenopausal women. ${ }^{13-1938-40}$

Our results also indicate that the elevated risk of breast cancer that smokers experience declined over time after smoking cessation, and it took up to 20 years for a former smoker's risk to return to baseline. Few studies have evaluated this relation in postmenopausal women, and their results were inconsistent. Some studies of predominantly postmenopausal women observed no relation between years since quitting smoking and breast cancer risk, ${ }^{15} 1618$ whereas other studies found results similar to ours. $^{2038}$

Our study is one of few prospective studies to observe a significantly increased risk of breast cancer associated with passive smoking among postmenopausal women. It seems unlikely that this could be explained by bias or confounding for several reasons. Firstly, our study is a prospective study, which circumvents problems of recall and selection bias common to case-control studies. In addition, the results remained similar when we excluded the first two years of followup (relative risk 1.38 (1.07 to 1.78) for the most extensive passive exposure). Secondly, we were able to adjust for all commonly known or suspected confounders for breast cancer. Thirdly, our study collected data on three major aspects of lifetime exposure (childhood, adult residential, and occupational), which enabled us to examine a reference group that had been unexposed to either active or passive smoking. Although our extensive variable of passive smoking exposure was 
Table $4 \mid$ Cases of incident invasive breast cancer and related hazard ratios among 79990 postmenopausal women by cancer subtypes and exposure to tobacco smoke

\begin{tabular}{|c|c|c|c|c|c|c|c|c|c|c|c|c|}
\hline & \multicolumn{7}{|c|}{ Passive smoking exposure* } & \multicolumn{5}{|c|}{ Active smoking status } \\
\hline & \multirow[b]{2}{*}{$\begin{array}{c}\text { Never† } \\
\text { No of } \\
\text { cases }\end{array}$} & \multicolumn{2}{|c|}{ Any exposure } & \multicolumn{2}{|c|}{$\begin{array}{c}\text { Non-extensive } \\
\text { exposure }\end{array}$} & \multicolumn{2}{|c|}{$\begin{array}{l}\text { Extensive } \\
\text { exposure }\end{array}$} & \multirow[b]{2}{*}{$\begin{array}{l}\text { Nevert } \\
\text { No of } \\
\text { cases }\end{array}$} & \multicolumn{2}{|c|}{ Former } & \multicolumn{2}{|c|}{ Current } \\
\hline & & $\begin{array}{l}\text { No of } \\
\text { cases }\end{array}$ & $\begin{array}{l}\text { Hazard } \\
\text { ratio } \\
(95 \% \mathrm{Cl})\end{array}$ & $\begin{array}{l}\text { No of } \\
\text { cases }\end{array}$ & $\begin{array}{l}\text { Hazard } \\
\text { ratio } \\
(95 \% \mathrm{Cl})\end{array}$ & $\begin{array}{l}\text { No of } \\
\text { cases }\end{array}$ & $\begin{array}{l}\text { Hazard } \\
\text { ratio } \\
(95 \% \mathrm{Cl})\end{array}$ & & $\begin{array}{l}\text { No of } \\
\text { cases }\end{array}$ & $\begin{array}{l}\text { Hazard } \\
\text { ratio } \\
(95 \% \mathrm{Cl})\end{array}$ & $\begin{array}{l}\text { No of } \\
\text { cases }\end{array}$ & $\begin{array}{c}\text { Hazard } \\
\text { ratio }(95 \% \\
\text { Cl) }\end{array}$ \\
\hline \multicolumn{13}{|c|}{ Cases defined by histology } \\
\hline $\begin{array}{l}\text { Ductal } \\
\text { cancer }\end{array}$ & 98 & 969 & $\begin{array}{c}1.02(0.83 \\
\text { to } 1.26)\end{array}$ & 878 & $\begin{array}{c}0.99(0.80 \\
\text { to } 1.23)\end{array}$ & 91 & $\begin{array}{l}1.20(0.90 \\
\text { to } 1.61)\end{array}$ & 1088 & 1013 & $\begin{array}{c}1.07(0.98 \\
\text { to } 1.18)\end{array}$ & 91 & $\begin{array}{c}1.16(0.97 \\
\text { to } 1.40)\end{array}$ \\
\hline $\begin{array}{l}\text { Lobular } \\
\text { cancer }\end{array}$ & 14 & 157 & $\begin{array}{l}1.22(0.70 \\
\text { to } 2.11)\end{array}$ & 147 & $\begin{array}{c}1.25(0.72 \\
\text { to } 2.17)\end{array}$ & 10 & $\begin{array}{l}0.97(0.43 \\
\text { to } 2.22)\end{array}$ & 175 & 164 & $\begin{array}{c}1.08(0.86 \\
\text { to } 1.35)\end{array}$ & 27 & $\begin{array}{c}1.64(1.09 \\
\text { to } 2.49)\end{array}$ \\
\hline \multicolumn{13}{|c|}{ Cases defined by hormone receptor } \\
\hline $\mathrm{OR}+\mathrm{PR}+$ & 93 & 941 & $\begin{array}{c}1.04(0.84 \\
\text { to } 1.29)\end{array}$ & 851 & $\begin{array}{c}1.01(0.82 \\
\text { to } 1.26)\end{array}$ & 90 & $\begin{array}{c}1.23(0.91 \\
\text { to } 1.65)\end{array}$ & 1052 & 1049 & $\begin{array}{c}1.12(1.03 \\
\text { to } 1.22)\end{array}$ & 139 & $\begin{array}{c}1.28(1.07 \\
\text { to } 1.53)\end{array}$ \\
\hline $\mathrm{OR}+\mathrm{PR}-$ & 18 & 184 & $\begin{array}{c}1.14(0.70 \\
\text { to } 1.86)\end{array}$ & 165 & $\begin{array}{c}1.09(0.67 \\
\text { to } 1.78)\end{array}$ & 19 & $\begin{array}{l}1.53(0.79 \\
\text { to } 2.94)\end{array}$ & 207 & 213 & $\begin{array}{c}1.18(0.97 \\
\text { to } 1.44)\end{array}$ & 13 & $\begin{array}{c}0.98(0.63 \\
\text { to } 1.53)\end{array}$ \\
\hline OR-PR- & 20 & 160 & $\begin{array}{c}1.10(0.69 \\
\text { to } 1.75)\end{array}$ & 193 & $\begin{array}{c}1.08(0.68 \\
\text { to } 1.72)\end{array}$ & 21 & $\begin{array}{c}1.39(0.74 \\
\text { to } 2.58)\end{array}$ & 237 & 194 & $\begin{array}{c}1.00(0.82 \\
\text { to } 1.22)\end{array}$ & 21 & $\begin{array}{c}0.98(0.65 \\
\text { to } 1.49)\end{array}$ \\
\hline
\end{tabular}

$\mathrm{OR}_{+}=$oestrogen receptor positive. $\mathrm{OR}-=$ oestrogen receptor negative. $\mathrm{PR+}=$ progesterone receptor positive. $\mathrm{PR}-=$ progesterone receptor negative.

*Analyses performed only among lifetime non-smokers.

†Reference categories for hazard ratios. For active smoking, all non-smokers formed the reference category regardless of passive smoking exposure.

$\ddagger$ Extensive exposure defined as exposure in childhood for $\geq 10$ years, in adult home for $\geq 20$ years, and in adult work for $\geq 10$ years.

defined a priori, there was no clear dose response to cumulative exposure, raising the possibility that the result was due to chance.

Previous epidemiological studies examining the association between passive smoking and breast cancer provided little evidence for a relation in postmenopausal women. ${ }^{16185-294142}$ However, all but one of these cohort studies had important limitations in terms of exposure assessment. Given the high prevalence of passive smoking exposure in the population (more than $80 \%$ of women in Western populations have been exposed to regular residential or occupational passive smoking exposure) ${ }^{20}$ inadequate assessment of exposure to passive smoking could have resulted in underestimating the passive smoking exposure status of most of those categorised as unexposed, thus contaminating the reference group and leading to an underestimate of risk. Johnson conducted a literature review and found that studies with more complete ascertainment of lifetime exposure, and which excluded women with passive smoking exposure from the reference group, consistently show higher breast cancer risks in association with passive smoking. ${ }^{20-2443}$ Recently, one cohort study that included a comprehensive measure of lifetime exposure to passive smoking ${ }^{30}$ also observed an increased risk in the most highly exposed subgroup of postmenopausal women whose passive smoking began after 20 years of age (hazard ratio 1.25 (1.01 to 1.56$)$ ).

\section{Possible biological mechanisms}

The association of both active and passive smoking with increased risk of breast cancer is biologically plausible, especially when exposure occurs during certain critical periods. Animal models have shown that mammary tissue may be particularly susceptible to carcinogenic exposures during the years from start of puberty to first full term pregnancy. ${ }^{1}$ Breast epithelial cells do not become fully differentiated until after the first full term pregnancy. Thus, the period between the onset of puberty and first full term pregnancy may be a time of higher risk of cancer initiation. ${ }^{44}$ Our findings of an elevated risk of breast cancer associated with early age of starting smoking ( $<15$ years old) and starting smoking before first full term pregnancy support the hypothesis that smoking during the early teenage years increases the risk of breast cancer. ${ }^{44}$ Alternatively, these results may simply be correlated with a long duration of smoking, which was also associated with increased risk in our cohort.

In addition, human biomarker studies have strongly suggested that breast tissue is a target for the carcinogenic effects of tobacco smoke. ${ }^{2}$ Studies have found that DNA adducts (DNA covalently bonded to a carcinogenic chemical) with derivatives of tobacco smoke are more common in the breast tissue of smokers than that of non-smokers. ${ }^{6546}$ The wide variation between people in DNA adduct formation and repair is likely related to a combination of factors, including the properties of individual carcinogens and host genetic poly morphisms. ${ }^{47}$ In 1996 Ambrosone et al reported that postmenopausal women who smoked and had the slow acetylator genotype for $\mathrm{N}$-acetyltransferase 2 had a significantly elevated risk of breast cancer. ${ }^{48} \mathrm{~A}$ recent meta-analysis of 13 studies of this association reached the same conclusion. ${ }^{49}$

Breast cancer is a heterogeneous disease with subtypes that may vary in their aetiologies. Our data sug gest that current smoking was more strongly associated with lobular cancer than with ductal cancer and with tumours that were hormone receptor positive (for both oestrogen and progesterone) than the other three combinations of receptor status. One study examining smoking in relation to the risk of different histological 


\section{WHAT IS ALREADY KNOWN ON THIS TOPIC}

Recent cohort studies have shown an increased risk of breast cancer among women who started smoking at a young age or who smoked for many years

An increased risk of breast cancer in women exposed to passive smoking has also been suggested but remains controversial

\section{WHAT THIS STUDY ADDS}

This cohort of postmenopausal women showed an increased risk of breast cancer among smokers, particularly those with high intensity and long duration of smoking

The study also found an increased risk of breast cancer among non-smokers with extensive exposure to passive smoking. However, the lack of significant association in other nonsmokers with lower exposure and no clear dose response to cumulative exposure mean the association between passive smoking and breast cancer should be considered suggestive only data were not collected for the intensity or frequency of passive smoke exposure. The crude measures and potential misclassification of exposure may make our estimate more conservative. The lack of intensity or frequency data also may have hampered our ability to detect a dose-response relation.

\section{Conclusions and policy implications}

Our study supports the hypothesis that active smoking is associated with an increased risk of breast cancer among postmenopausal women. In addition, our data suggest that extensive exposure to passive smoking may increase breast cancer risk. However, since risk of breast cancer was restricted to the most extensive passive smoking category with no clear dose response, the association with passive smoking should be considered suggestive only and needs confirmation from other studies. Our findings highlight the need for interventions to prevent initiation of smoking, especially at an early age, and to encourage smoking cessation at all ages. Future studies examining how genetic polymorphisms and other risk factors modify the effect of tobacco exposure on breast cancer risk are likely to further our understanding of this important issue.

Funding: The Women's Health Initiative is funded by the National Heart, Lung, and Blood Institute, National Institutes of Health, US Department of Health and Human Services (contracts N01WH22110, 24152, 32100-2, 32105-6, 32108-9, 32111-13, 32115, 32118-32119, 32122, 42107-26, 42129-32, and 44221). The funding source had no role in the collection, analysis, or interpretation of the data, in the preparation of the manuscript, or its submission for publication.

Contributors: JL, KLM, and JWW participated in the study design. JL completed the data analysis. All authors participated in data collection, data interpretation, and drafting the manuscript. KLM is guarantor for the study.

Competing interests: All authors have completed the Unified Competing Interest form at www.icmje.org/coi_disclosure.pdf (available on request from the corresponding author) and declare: support from the National Heart, Lung, and Blood Institute for the submitted work as described above; no financial relationships with any organisations that might have an interest in the submitted work in the previous three years; no other relationships or activities that could appear to have influenced the submitted work.

Ethical approval: This study was approved by the ethics committees at the Women's Health Initiative Coordinating Center, Fred Hutchinson Cancer Research Center, and at all 40 clinical centres.

Data sharing: No additional data available. passive smoking, including quantitative measures exposure in childhood and adult exposure in residential and workplace settings.

However, our study also has limitations. One is that we used only baseline values for women's smoking status and all covariates and did not account for changes in exposure during follow-up, which may have caused some exposure misclassification and biased our results towards the null. However, given that our study population consisted of postmenopausal women and that few were current smokers, the effect of changes in smoking status during follow-up is likely to have been minimal. Based on yearly reassessment of smoking status in the Women's Health Initiative, about $60 \%$ of smokers continued to smoke for six years of follow-up and 99\% of non-smokers remained abstinent.

Secondly, there was possible recall bias with regard to passive smoking exposure in childhood. In addition,
1 International Agency for Research on Cancer. IARC monographs on the evaluation of carcinogenic risk of chemicals to humans. IARC, 2004.

2 Conway K, Edmiston SN, Cui L, Drouin SS, Pang J, He M, et al. Prevalence and spectrum of $\mathrm{p} 53$ mutations associated with smoking in breast cancer. Cancer Res 2002;62:1987-95.

3 Li D, Zhang W, Sahin AA, Hittelman WN. DNA adducts in normal tissue adjacent to breast cancer: a review. Cancer Detect Prev 1999;23:454-62.

4 Rundle A, Tang D, Hibshoosh H, Estabrook A, Schnabel F, Cao W, et al. The relationship between genetic damage from polycyclic aromatic hydrocarbons in breast tissue and breast cancer. Carcinogenesis 2000;21:1281-9.

5 Li D, Wang M, Dhingra K, Hittelman WN. Aromatic DNA adducts in adjacent tissues of breast cancer patients: clues to breast cance etiology. Cancer Res 1996;56:287-93.

6 Firozi PF, Bondy ML, Sahin AA, Chang P, Lukmanji F, Singletary ES, et al. Aromatic DNA adducts and polymorphisms of CYP1A1, NAT2, and GSTM1 in breast cancer. Carcinogenesis 2002;23:301-6.

7 Hamajima N, Hirose K, Tajima K, Rohan T, Calle EE, Heath CW Jr, et al. Alcohol, tobacco and breast cancer-collaborative reanalysis of individual data from 53 epidemiological studies, including 58,515 
women with breast cancer and 95,067 women without the disease. BrJ Cancer 2002;87:1234-45.

8 Palmer JR, Rosenberg L. Cigarette smoking and the risk of breast cancer. Epidemiol Rev 1993;15:145-56.

9 Terry PD, Rohan TE. Cigarette smoking and the risk of breast cancer in women: a review of the literature. Cancer Epidemiol Biomarkers Prev 2002;11:953-71.

10 The 2004 United States Surgeon General's Report: the health consequences of smoking. N S W Public Health Bull 2004;15:107.

11 Kopans DB. Standardized mammography reporting. Radiol Clin North Am 1992;30:257-64.

12 Collishaw NE, Boyd NF, Cantor KP, Hammond SK, Johnson KC, Millar J, et al. Canadian expert panel on tobacco smoke and breast cancer risk. Ontario Tobacco Research Unit, 2009. www.otru.org/pdf/special/ expert_panel_tobacco_breast_cancer.pdf.

13 Olson JE, Vachon CM, Vierkant RA, Sweeney C, Limburg PJ, Cerhan JR, et al. Prepregnancy exposure to cigarette smoking and subsequent risk of postmenopausal breast cancer. Mayo Clin Proc 2005;80:1423-8.

14 Gram IT, Braaten T, Terry PD, Sasco AJ, Adami HO, Lund E, et al. Breas cancer risk among women who start smoking as teenagers. Cancer Epidemiol Biomarkers Prev 2005;14:61-6.

15 Cui Y, Miller AB, Rohan TE. Cigarette smoking and breast cancer risk: update of a prospective cohort study. Breast Cancer Res Treat 2006;100:293-9.

16 Reynolds P, Hurley S, Goldberg DE, Anton-Culver H, Bernstein L, Deapen D, et al. Active smoking, household passive smoking, and breast cancer: evidence from the California Teachers Study. I Nat Cancer Inst 2004;96:29-37.

17 Al-Delaimy WK, Cho E, Chen WY, Colditz G, Willet WC. A prospective study of smoking and risk of breast cancer in young adult women. Cancer Epidemiol Biomarkers Prev 2004;13:398-404.

18 Egan KM, Stampfer MJ, Hunter D, Hankinson S, Rosner BA, Holmes $\mathrm{M}$, et al. Active and passive smoking in breast cancer: prospective results from the Nurses' Health Study. Epidemiology 2002;13:138-45

19 Ha M, Mabuchi K, Sigurdson AJ, Freedman DM, Linet MS, Doody MM, et al. Smoking cigarettes before first childbirth and risk of breast cancer. Am J Epidemiol 2007;166:55-61.

20 Johnson KC, Hu J, Mao Y. Passive and active smoking and breast cancer risk in Canada, 1994-97. Cancer Causes Control 2000;11:211-21.

21 Kropp S, Chang-Claude J. Active and passive smoking and risk of breast cancer by age 50 years among German women. $\mathrm{Am}$ Epidemiol 2002;156:616-26.

22 Morabia A, Bernstein M, Heritier S, Khatchatrian N. Relation of breast cancer with passive and active exposure to tobacco smoke. Am J Epidemiol 1996;143:918-28.

23 Smith SI, Deacon JM, Chilvers CE. Alcohol, smoking, passive smoking and caffeine in relation to breast cancer risk in young women. UK National Case-Control Study Group. Br J Cancer 1994;70:112-9.

24 Zhao Y, Shi Z, Liu L. [Matched case-control study for detecting risk factors of breast cancer in women living in Chengdu.] Zhonghua Liu Xing Bing Xue Za Zhi 1999;20:91-4.

25 Wartenberg D, Calle EE, Thun MJ, Heath CW Jr, Lally C, Woodruff T. Passive smoking exposure and female breast cancer mortality. J Nat Cancer Inst 2000;92:1666-73.

26 Pirie K, Beral V, Peto R, Roddam A, Reeves G, Green J. Passive smoking and breast cancer in never smokers: prospective study and meta-analysis. Int J Epidemiol 2008;37:1069-79.

27 Hanaoka T, Yamamoto S, Sobue T, Sasaki S, Tsugane S. Active and passive smoking and breast cancer risk in middle-aged Japanese women. Int J Cancer 2005;114:317-22.

28 Wells AJ. Breast cancer, cigarette smoking, and passive smoking. Am J Epidemiol 1991;133:208-10.

29 Jee SH, Ohrr H, Kim IS. Effects of husbands' smoking on the incidence of lung cancer in Korean women. Int J Epidemiol 1999;28:824-8.

30 Reynolds P, Goldberg D, Hurley S, Nelson DO, Largent J, Henderson KD, et al. Passive smoking and risk of breast cancer in the California teachers study. Cancer Epidemiol Biomarkers Prev 2009;18:3389-98.

31 The Women's Health Initiative Study Group. Design of the Women's Health Initiative clinical trial and observational study. Control Clin Trials 1998;19:61-109.

32 Hays J, Hunt IR, Hubbell FA, Anderson GL, Limacher M, Allen C, et al. The Women's Health Initiative recruitment methods and results. Ann Epidemiol 2003;13(suppl 9):18-77S.

33 Langer RD, White E, Lewis CE, Kotchen JM, Hendrix SL, Trevisan M. The Women's Health Initiative Observational Study: baseline characteristics of participants and reliability of baseline measures. Ann Epidemiol 2003;13(suppl 9):107-21S.

34 Surveillance Epidemiology and End Results. SEER extent of disease: 1988 codes and coding instructions. 3rd ed. National Cancer Institute, US National Institutes of Health, 1998. http://seer.cancer. gov/manuals/EOD10Dig.3rd.pdf.

35 Hammond SK. Exposure of US workers to environmental tobacco smoke. Environ Health Perspect 1999;107(suppl 2):329-40.

36 Hammond SK, Sorensen G, Youngstrom R, Ockene JK. Occupational exposure to environmental tobacco smoke. JAMA 1995;274:956-60.

37 Hess KR. Graphical methods for assessing violations of the proportional hazards assumption in Cox regression. Stat Med 1995; 14:1707-23.

$38 \mathrm{Li} \mathrm{Cl}$, Malone KE, Daling JR. The relationship between various measures of cigarette smoking and risk of breast cancer among older women 65-79 years of age (United States). Cancer Causes Control 2005;16:975-85.

39 Band PR, Le ND, Fang R, Deschamps M. Carcinogenic and endocrine disrupting effects of cigarette smoke and risk of breast cancer. Lance 2002;360:1044-9.

40 Lissowska J, Brinton LA, Zatonski W, Blair A, Bardin-Mikolajczak A, Peplonska B, et al. Tobacco smoking, NAT2 acetylation genotype and breast cancer risk. Int / Cancer 2006;119:1961-9.

41 Miller MD, Marty MA, Broadwin R, Johnson KC, Salmon AG, Winder B, et al. The association between exposure to environmental tobacco smoke and breast cancer: a review by the California Environmental Protection Agency. Prev Med 2007;44:93-106.

42 Department of Health and Human Services. The health consequences of involuntary exposure to tobacco smoke: a report of the Surgeon General. US Department of Health and Human Services, 2006.

43 Johnson KC. Accumulating evidence on passive and active smoking and breast cancer risk. Int / Cancer 2005;117:619-28.

44 Palmer JR, Rosenberg L, Clarke EA, Stolley PD, Warshauer ME, Zauber AG, et al. Breast cancer and cigarette smoking: a hypothesis. Am J Epidemiol 1991;134:1-13.

45 Perera FP, Estabrook A, Hewer A, Channing K, Rundle A, Mooney LA, et al. Carcinogen-DNA adducts in human breast tissue. Cancer Epidemiol Biomarkers Prev 1995;4:233-8.

46 Faraglia B, Chen SY, Gammon MD, Zhang Y, Teitelbaum SL, Neugut Al, et al. Evaluation of 4-aminobiphenyl-DNA adducts in human breast cancer: the influence of tobacco smoke. Carcinogenesis 2003;24:719-25.

47 Harris CC. Interindividual variation among humans in carcinogen metabolism, DNA adduct formation and DNA repair. Carcinogenesis 1989;10:1563-6.

48 Ambrosone CB, Freudenheim JL, Graham S, Marshall JR, Vena JE, Brasure JR, et al. Cigarette smoking, $\mathrm{N}$-acetyltransferase 2 genetic polymorphisms, and breast cancer risk. JAMA 1996;276:1494-501.

49 Ambrosone CB, Kropp S, Yang J, Yao S, Shields PG, Chang-Claude J. Cigarette smoking, $\mathrm{N}$-acetyltransferase 2 genotypes, and breast cancer risk: pooled analysis and meta-analysis. Cancer Epidemio Biomarkers Prev 2008;17:15-26.

50 Rosenberg LU, Magnusson C, Lindstrom E, Wedren S, Hall P, Dickman PW. Menopausal hormone therapy and other breast cance risk factors in relation to the risk of different histological subtypes of breast cancer: a case-control study. Breast Cancer Res 2006;8:R11.

51 Manjer J, Malina J, Berglund G, Bondeson L, Garne JP, Janzon L. Smoking associated with hormone receptor negative breast cancer. Int / Cancer 2001;91:580-4.

52 Cooper JA, Rohan TE, Cant EL, Horsfall DJ, Tilley WD. Risk factors for breast cancer by oestrogen receptor status: a population-based case-control study. Br J Cancer 1989;59:119-25.

53 London SJ, Colditz GA, Stampfer MJ, Willett WC, Rosner BA Speizer FE. Prospective study of smoking and the risk of breast cancer. J Natl Cancer Inst 1989;81:1625-31.

54 Yoo KY, Tajima K, Miura S, Takeuchi T, Hirose K, Risch H, et al. Breast cancer risk factors according to combined estrogen and progesterone receptor status: a case-control analysis. $\mathrm{Am}$ Epidemiol 1997;146:307-14.

55 Althuis MD, Fergenbaum JH, Garcia-Closas M, Brinton LA, Madigan MP, Sherman ME. Etiology of hormone receptor-defined breast cancer: a systematic review of the literature. Cancer Epidemio Biomarkers Prev 2004;13:1558-68.

56 Kabat GC, Kim M, Kakani C, Tindle H, Wactawski-Wende J, Ockene JK, et al. Cigarette smoking in relation to risk of ductal carcinoma in situ of the breast in a cohort of postmenopausal women. Am J Epidemiol 2010;172:591-9.

Accepted: 11 January 2011 